\title{
Short Communication: \\ Diversity of medicinal plants used to treat human ailments in rural Bahir Dar, Ethiopia
}

\author{
ETHIOPIA MAZENGIA ${ }^{1}$, TADESSE BEYENE ${ }^{2}$, BERHANU A. TSEGAY, \\ ${ }^{1}$ Department of Biology, Bule Hora University. Hagere Maryam, Etiopia. \\ ${ }^{2}$ Department of Biology, Mekelle University. Mekelle, Ethiopia \\ ${ }^{3}$ Department of Biology, Bahir Dar University. Bahir Dar, Ethiopia. "email: berhanu.tsegay@ gmail.com
}

Manuscript received: 11 July 2019. Revision accepted: 29 October 2019.

\begin{abstract}
Mazengia E, Beyene T, Tsegay BA. 2019. Short Communication: Diversity of medicinal plants used to treat human ailments in rural Bahir Dar, Ethiopia. Asian J For 3: 75-82. Survey of traditional medicinal plants used to treat human ailments by the rural community of Bahir Dar City Administration was conducted from November 23, 2017 to May 30, 2018 with the aim of identifying and documenting plants and the associated knowledge used to treat humans. We collected data from six study sites using semi-structured interviews, field observation and group discussion. Data analyses were made using preference ranking, direct matrix ranking and fidelity level index. A total of 77 medicinal plants were identified. The majority of plants $(58.4 \%)$ were harvested from the wild. The largest number of plants were herbs $(42.6 \%)$ followed by shrubs $(32.6 \%)$. The most frequently used plant parts in human disease treatments were leaves $(54 \%)$ followed by roots (18\%). Most remedies were prepared by pounding and mixing (concoction) (36\%). The remedial administration was mostly oral (51\%) followed by dermal (31\%). Allium sativum and Ocimum lamiifolium were the most frequently used. The community in the study area used considerable diversity of plant species for maintaining their health care system. Nonetheless, conservation for those plants whose roots are harvested is necessary.
\end{abstract}

Keywords: Ethnobotany, ethnomedicine, ex-situ, in-situ, traditional healer, use value

\section{INTRODUCTION}

People have used plants for multiple purposes, i.e., as sources of food, medicines for human beings, livestock fodder, and as materials for household utensils, fuel, etc. Traditional medicine is culturally-based cure system different from modern (scientific) medicine and is usually considered as indigenous, alternative or folk medicine, which is largely transmitted by words of mouth from elders to the young generation (Martin 1995). Most people in the world (70-90\%) use herbal remedies as their primary healthcare system (Nair and Nathan 1998).

Ethiopia is endowed with a wide range of topographic features enabling it to have a variety of ecosystems. These varied ecosystems possess high diversity of flora and fauna which include good number of potentially useful medicinal plants (Abebe 1986; Seid and Tsegay 2011). Majority of Ethiopians (about 80\%) use herbal medicine as their primary healthcare system (Giday 1999). However, high rate of land-use conversion (deforestation for agricultural land expansion), over-harvesting and/ or indiscriminate harvesting and unmanaged population growth with increasing demand and consumption are the principal problems that aggravate the rate of disappearance of medicinal plants from their habitat and the consequent loss of significant number of plant species (Seifu et al. 2006).

All culturally useful medicinal plants have not been surveyed and documented in Ethiopia. The traditional knowledge and practices around Bahir Dar City are part of the non-surveyed ones. This study aimed to identify and document the medicinal plants used by the rural community of Bahir Dar and the associated knowledge used to treat humans. Such a study would be of paramount importance in conserving the plants and ensuring their sustainable use. Moreover, bequeathing the traditional knowledge to the next generation and developing it for new insights is necessary.

\section{MATERIALS AND METHODS}

\section{Study location}

Ethnomedicinal study was conducted in Bahir Dar rural kebeles (smallest administrative units in Ethiopia) (Figure1) from November 23, 2017 to May 30, 2018. Bahir Dar is located at $11^{\circ} 59^{\prime}$ North latitude and $37^{\circ} 39^{\prime}$ East longitude as determined from the city center. The elevation ranged from 1650 m.a.s.l at Tisabay to 2100 m.a.s.l at Meshenti. From the 26,295 hectares area of the rural kebeles, 19,969 hectares of the land is being cultivated (ANRS RLUM, 2018 personal communication). According to fourteen years' metrological data obtained from Bahir Dar city weather station, the study area received mean annual rainfall and temperature of $1423.2 \mathrm{~mm}$ and $27.5^{\circ} \mathrm{C}$, respectively (ANRS RLUM, 2018 personal communication). 


\section{Informant selection}

Six kebeles (small local administrative units) were selected purposely based on the availability of local healers as advised by community elders (Figure 1). Totally 72 informants, consisting of 35 men and 37 women, were selected for this study. Seven key informants, one from each kebele except 2 from TisAbay, were selected based on the advice from local authorities, traditional healers and local farmers. The remaining 65 general informants were randomly selected.

\section{Ethnobotanical data collection}

The primary data were collected directly from the informants in the study area by semi-structured interviews, group and individual-focused discussions, field visits and informal conversations. During group discussion, necessary information related to medicinal plants, mode of preparation, method of application, types of disease treated, plant parts used for preparation of remedies were documented to obtain detailed quantitative and qualitative data. The plants were identified using different volumes of "Flora of Ethiopia and Eritrea" (https://www.nhbs.com/series/flora-of-ethiopia-and-eritrea)
(Edwards et al. 2000; Hedberg and Edwards 1989, 1995; Hedberg et al. 1995, 1997, 2003, 2007, 2009a, 2009b; Tadesse. 2005), as well as Bekele-Tesemma (2007) and Dagne (2009). Online references were also used (Table 1).

\section{Data analysis}

Descriptive statistics (Microsoft Excel 2010) was used to analyze data. Information provided by respondents was determined using preference ranking, direct matrix ranking and fidelity level index following the method from Alexiades (1996) and Martin (1995).

\section{RESULTS AND DISCUSSION}

Most of the medicinal plants used by the traditional healers in rural kebeles of Bahir Dar are presented in Table 1. Seventy-seven (77) ethnomedicinal plant species belonging to 75 genera and 42 families were collected with the guidance of local healers. Out of the 77 species, $58.4 \%$ were from the wild and $27.3 \%$ were cultivated while $14.3 \%$ were both wild and cultivated.

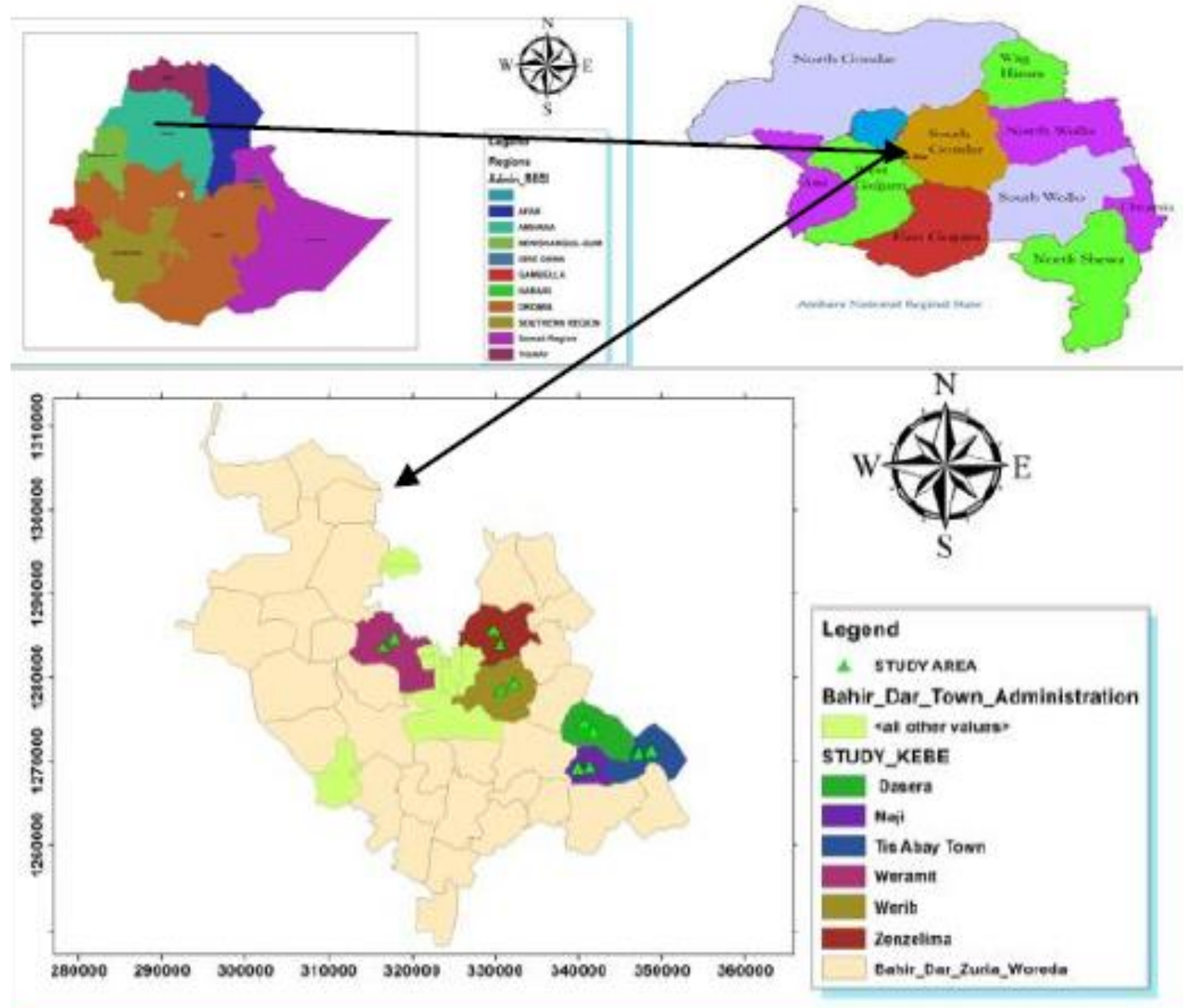

Figure 1. Map of the study area (drawn by Andargachew Baye, member of the GIS team, Amhara National Regional State, Ethiopia) 
Table 1. List of major traditional medicinal plants used to treat human ailments in rural community of Bahir Dar City Administration, Ethiopia. In total there were 77 medicinal plants recorded.

\begin{tabular}{|c|c|c|c|c|}
\hline Botanical and family name & Online reference & $\begin{array}{c}\text { Local name } \\
\text { (Amharic) }\end{array}$ & Ailment treated & $\begin{array}{l}\text { Part used for preparation and their application as } \\
\text { reported by healers. }\end{array}$ \\
\hline $\begin{array}{l}\text { Achyranthes aspera } \mathrm{L} \\
\text { (Amaranthaceae) }\end{array}$ & $\begin{array}{l}\text { https://keys.lucidcentral.org/keys/v3/eafrinet } \\
\text { /weeds/key/weeds/Media/Html/Achyranthes } \\
\text { _aspera_(Devils_Horsewhip).htm }\end{array}$ & Telenge & Hemorrhoids & $\begin{array}{l}\text { The leaf is pounded, squeezed and then creamed on infected } \\
\text { part. }\end{array}$ \\
\hline $\begin{array}{l}\text { Allium cepa } \mathrm{L} . \\
\text { (Alliaceae ) }\end{array}$ & $\begin{array}{l}\text { https://www.prota4u.org/database/protav8.a } \\
\text { sp?g=pe\&p=Allium+cepa+L. }\end{array}$ & Kei shinkurt & $\begin{array}{l}\text { Stomach complaints, } \\
\text { Cough }\end{array}$ & $\begin{array}{l}\text { Pound the stem and mix with } A \text {. sativum, } R \text {. chalepensis and } \\
\text { honey. Then eat them every morning until getting recovered. }\end{array}$ \\
\hline $\begin{array}{l}\text { Allium sativum } \mathrm{L} \\
\text { (Liliaceae) }\end{array}$ & $\begin{array}{l}\text { https://www.sciencedirect.com/topics/pharm } \\
\text { acology-toxicology-and-pharmaceutical- } \\
\text { science/allium-sativum }\end{array}$ & Nech shinkurt & Malaria & $\begin{array}{l}\text { Pound, mix with Cicer arietinum for night long and eat them } \\
\text { in the morning. }\end{array}$ \\
\hline $\begin{array}{l}\text { Argemone mexicana } \mathrm{L} . \\
\text { (Papaveraceae) }\end{array}$ & $\begin{array}{l}\text { https://plants.usda.gov/core/profile?symbol= } \\
\text { arme } 4\end{array}$ & Yaheya eshoh & Wound & Apply the latex on the wound or use it as massage cream. \\
\hline $\begin{array}{l}\text { Artemisia abyssinica } \\
\text { Shc.Bip.ex.A.Rich } \\
\text { (Asteraceae) }\end{array}$ & $\begin{array}{l}\text { https://www.prota4u.org/database/protav8.a } \\
\text { sp?g=psk\&p=Artemisia+abyssinica+Sch.Bi } \\
\text { p.+ex+A.Rich. }\end{array}$ & Chikugn & $\begin{array}{l}\text { Stomach complaints (ache) } \\
\text { with diarrhea }\end{array}$ & Dried leaf is ground \& mixed with water and drunk. \\
\hline $\begin{array}{l}\text { Arundo donax } \mathrm{L} \\
\text { (Poaceae) }\end{array}$ & $\begin{array}{l}\text { https://www.invasive.org/browse/subinfo.cf } \\
\text { m?sub=3009 }\end{array}$ & Shenbeko & Rh factor "shotelay" & The root of Arundo donax is tied to neck. \\
\hline $\begin{array}{l}\text { Brassica carinata A. Braun } \\
\text { (Brassicaceae) }\end{array}$ & $\begin{array}{l}\text { http://www.africanplants.senckenberg.de/ro } \\
\text { ot/index.php?page_id=78\&id=3529\# }\end{array}$ & Yabesha gomen & Placental retention (delay) & $\begin{array}{l}\text { Roasted and grounded, then mixed with leaf juice of } \\
\text { Ziziphus spina-christi in hot water. Then drink or place it in } \\
\text { vagina. }\end{array}$ \\
\hline $\begin{array}{l}\text { Brucea antidysenterica J.F.Mil } \\
\text { (Simaroubaceae) }\end{array}$ & $\begin{array}{l}\text { https://www.prota4u.org/database/protav8.a } \\
\text { sp?g=pe\&p=Brucea+antidysenterica+J.F.Mi } \\
\text { ll. }\end{array}$ & Waginose & Wound & $\begin{array}{l}\text { The leaf of Brucea antidysenterica is pounded, squeezed and } \\
\text { then creamed on wounded part until getting recovered. }\end{array}$ \\
\hline $\begin{array}{l}\text { Carica papaya } \mathrm{L} \\
\text { (Caricaceae) }\end{array}$ & $\begin{array}{l}\text { https://florafaunaweb.nparks.gov.sg/Special- } \\
\text { Pages/plant-detail.aspx?id=2785 }\end{array}$ & Papaye & Swelling & $\begin{array}{l}\text { Split the fruit and remove seeds and their content. Use the } \\
\text { pulp as massage cream on the infected body part }\end{array}$ \\
\hline $\begin{array}{l}\text { Carissa spirnarum } \mathrm{L} \text {. } \\
\text { (Apocynaceae) }\end{array}$ & https://www.gbif.org/species/5536282 & Agam & Devil disease & $\begin{array}{l}\text { Boil fruit and mix with roots of } P \text { schimperi, } C \text {. } \\
\text { macrostachyus \& A. schimperiana and drink the suspension. }\end{array}$ \\
\hline $\begin{array}{l}\text { Catha edulis (Vahl) Forssk. ex } \\
\text { Endl. } \\
\text { (Celastraceae) }\end{array}$ & $\begin{array}{l}\text { https://www.prota4u.org/database/protav8.a } \\
\text { sp?g=pe\&p=Catha+edulis+(Vahl)+Forssk.+ } \\
\text { ex+Endl. }\end{array}$ & Chat & Asthma/Coughing & $\begin{array}{l}\text { The leaf powder is mixed with melted butter and drink it in } \\
\text { the morning until getting recovered. }\end{array}$ \\
\hline $\begin{array}{l}\text { Chenopodium ambrosioides } \\
\text { (Chenopodiaceae) }\end{array}$ & $\begin{array}{l}\text { http://bioweb.uwlax.edu/bio203/2011/mccar } \\
\text { thy_mega/Medicinal_uses.htm }\end{array}$ & Amedmado & Infection on swelling & $\begin{array}{l}\text { Pounded plant is mixed with Datura stramonium } L \\
\text { \&Kalanchoe sp and bandages them on the swelling. }\end{array}$ \\
\hline Coffee arabica L. (Rubiaceae) & $\begin{array}{l}\text { http://powo.science.kew.org/taxon/urn:lsid:i } \\
\text { pni.org:names:747038-1 }\end{array}$ & Buna & Wound sore & $\begin{array}{l}\text { The seed is roasted \& pounded (powdered) and put on the } \\
\text { wound until it is healed. }\end{array}$ \\
\hline $\begin{array}{l}\text { Croton macrostachyus Hochst. } \\
\text { ex Delile (Euphorbiaceae) }\end{array}$ & $\begin{array}{l}\text { https://www.prota4u.org/database/protav8.a } \\
\text { sp?g=pe\&p=Croton+macrostachyus+Hochst } \\
.+ \text { ex+Delile }\end{array}$ & Bisana & Face fungus (Tinea faiei) & $\begin{array}{l}\text { Mixed leaf extract with A. sativum\& honey. Then apply it on } \\
\text { the infected body. }\end{array}$ \\
\hline $\begin{array}{l}\text { Cucurbita pepo L } \\
\text { (Cucurbitaceae) }\end{array}$ & $\begin{array}{l}\text { http://powo.science.kew.org/taxon/urn:lsid:i } \\
\text { pni.org:names:292416-1 }\end{array}$ & Duba & Tape warm & Powdered seed is mixed with butter and eaten \\
\hline
\end{tabular}


Cyathula polycephala Beker (Amaranthaceae)

Dovyalis abyssinica A.Rich. (Salcaiaceae)

Embelia schimperi Vatke

(Myrsinaceae)

Euphorbia ampliphylla $\mathrm{L}$

(Euphorbiaceae)

Foeniculm vulgare Miller (Apiaceae)

Justicia schimperiana

(Hochst.ex A. Nees)T.Ander

(Acanthaceae)

Kalanchoe petitiana A.Rich

(Crassulaceae)

Len sculinaris Medik

(Fabaceae)

Lepidium sativum $\mathrm{L}$.

(Cruciferae)

Linum usitatissimum $\mathrm{L}$

(Linaceae)

Lonchocarpus laxiflorus

Guill.Perr (Leguminosae)

Lycopersicon esculentum Mill.

(Solanaceae)

Mentha x piperita L.

(Labiatae)

Moringa oleifera $\mathrm{L}$

(Moringaceae)

Optica ficus-indica (L) Mill. (Moraceae)

Otostegiaint egrifilia Benth.

(Lamiaceae)

Phytolacca dodecandra $\mathrm{L}$

(Phytolacaceae)

Piper nigra L. (Piperaceae) http://www.villege.ch/musinfo/bd/cjb/africa/ Chegogot details.php?langue $=$ an $\&$ id $=34$

https://www.pfaf.org/user/Plant.aspx?Latin Koshm Name $=$ Dovyalis + abyssinica

http://www.westafricanplants.senckenberg.d Inkoko e/root/index.php?page_id=14\&id=3116

WCSP (World Checklist of Selected Plant Qulquale

Families)

https://www.hindawi.com/journals/bmri/201 Inslal 4/842674/

http://www.africanplants.senckenberg.de/ro Smiza

ot/index.php?page id=78\&id=5715

http://www.africanplants.senckenberg.de/ro ot/index.php?page_id=78\&id=5657

http://eol.org/pages/647510/overview

http://www.tela-botanica.org/bdtfx-nn-

75217-synthese

http://swbiodiversity.org/seinet/taxa/index.p Telba

hp?taxon=2472

http//www westafricanplants.senckenberg.d Amera

e/root/index.php?page_id=14\&id=1989

http://www.theplantlist.org/tpl/record/tro- Timatim

29602513

https:/www.avogel.ch/en/plant-

encyclopaedia/mentha_x_piperita.php

http://www.africanplants.senckenberg.de/ro

ot/index.php?page_id=78\&id=1115\#image $=$

57870

http://www.theplantlist.org/tpl1.1/record/ke w-2391911

https://botany.cz/cs/rydingia-integrifolia/

Tinjute

http://tropical.theferns.info/viewtropical.php Endod

?id=Phytolacca+dodecandra

http//powo science kew org/taxon/urn-lsid:i pni.org:names:682369-1
Skin rash ("chiffee")

Abdominal pain

Tapeworm

STDs

Gonorrhea

kuruba'

stomach ache

'Ebach'(lymphadenopathy)

Diabetes

Stomach complaints

Retained placenta

Diabetes

Eye disease

Diarrhea

Tumor

Ringworm (Tinea corporis)

Stomach-ache

Miscarriage (abortion unwanted pregnancy)

Stomach complaints
The leaf of Cyathula polycephala is crushed, squeezed and the pure solution is applied to affected body part until getting recovered

Eat six to ten fruits

drink water with powdered seed

The drop of latex is collected, mixed with Eragrostis teff powdered and backed and then eaten before any food for 3 days

Leaf is mixed with Lepidium sativum(seed) and eaten.

The leaf is crushed and drink the leaf latex

head leaf dressing on the infected part until the tumor is removed

Eat the seed of Len sculinaris in the morning

Ground seed is mixed with water and then eat

The seed of Linum usitatissimum is mixed with water and boiled and then drink the solution after being cooled.

Boil a leaf and drink it without sugar

The seed of Lycopersiconesculentum is eaten

Pound the leaf and mix with A. sativum, $R$. chalepensis, and drink them

Pound the leaf and apply on the tumor

Add leaf secretion on the infected skin

Juice the leaf with water and drink it

Qundoberbere of Pound, squeeze and mix with water then drink it

Pound the seed and mix with N.sativa, Z.officinalis, $R$ chalepensis \& A.sativum; then leave for 7 days and eat every morning during pain 
Podocarpus falcatus (Thunb) http://pza.sanbi.org/podocarpus-falcatus

R.Br.ex Mirb.

(Podocapaceae)

Rhamnus prinoides $\mathrm{L} \mathrm{Her}$

(Rhamnaceae)

Ricinus communis L.

(Euphorbiaceae)

Rumex abyssinica Jacq.

(Polygonaceae)

Rumex nervosus Vahl

(Polygonaceae)

Ruta chalepensis $\mathrm{L}$

(Rutaceae)

Senna singueana Deal Lock

(Fabaceae )

Sida tenuicarpa Vollesen

(Malvaceae)

Sida rhombifoliaL.

(Malvaceae)

Solanum dasyphyllum

Schumach \& Thonn.

(Solanaceae)

Thymus schemperi Ronniger.

(Lamiaceae)

Tragia cinerea (pax)

M.G.Gillbert \& Radcl.-SM.

(Euphorbiaceae)

Trigonella foenum-graecum $\mathrm{L}$.

(Leguminosae)

Triumfetta pilosa Roth.

(Tiliaceae)

Urtica simensis Host. ex

Steudel

(Urticaceae)

Vernonia amygdalina Del.

(Asteraceae)

http://pza.sanbi.org/rhamnus-prinoides

https://plants.usda.gov/core/profile?symbol= rico3

https://www.prota4u.org/database/protav8.as

$\mathrm{p}$ ? $=$ pe \&p=Rumex + abyssinicus + Jacq.

https://www.prota4u.org/database/protav8.a

$\mathrm{sp}$ ? $=$ psk\&p=Rumex + nervosus + Vahl

http://www.maltawildplants.com/RUTA/Rut

a_chalepensis.php

https://www.researchgate.net/figure/Photogr

aphs-of-Senna-singueana-Del-Lock-

Fabaceae-and-the-collected-

leaves_fig2_273791660

https://botany.cz/cs/sida-tenuicarpa/

https://keyserver.lucidcentral.org/weeds/data $/ \mathrm{media} / \mathrm{Html} /$ sida rhombifolia.htm

http://www.westafricanplants.senckenberg.d e/root/index.php?page_id=14\&id=2608

http://www.africanplants.senckenberg.de/ro ot $/$ index.php?page $\mathrm{id}=78 \& \mathrm{id}=4789$

http://www.tropicos.org/Name/12806195?ta $\mathrm{b}=$ images

http://flora.org.il/en/plants/TRIFOE/

https://www.prota4u.org/database/protav8.as $\mathrm{p} ? \& \mathrm{~g}=\mathrm{pe} \& \mathrm{p}=$ Triumfetta+pilosa+Roth

https://plants.jstor.org/stable/history/10.555

5/al.ap.specimen.hal011 0249

https://www.yumpu.com/en/document/view/ 41885798/vernonia-amygdalina-asteraceaedel-world-agroforestry-centre/2

Withania somnifera ( L) Dunal (Solanaceae)

Zingiber officinale Rosc

(Zingiberaceae) $\mathrm{n}=\mathrm{com} \_$content $\&$ view $=$ article $\& \mathrm{id}=102052: \mathrm{z}$
Gesho

Tonsillitis

Amoeba

'Dembizat' (Hypertension)

Hepatitis

Stroke (Syncope)

Cerebral hypoxia

Swelling

Gufa

Chifrig

Gorgegit

Embuay

Tosign

Aleblabet

Abish

Shemgegit

Sama

Girawa

Gizawa

http://www.globinmed.com/index.php?optio Zinjibile ingiber-officinale-

rosc \& catid=209\&Itemid $=143$
Erectile dysfunction

Wound

Physical damage

Cough

Evel eye

Diabetic

Evel Eye

Heart failure

Ascariasis

Babies Disease

Common cold
Pound the seed mix with Artemisia rehan then squeeze and drink it

Dried seed is chewed during stomach ache

The leaf powder is boiled with water and drink the juice

A leaf is pounded \& boiled and drink a cup of it before breakfast

or The leaf is pounded or ground, mix it with water and drink it every morning

Dried leaf, stem, root, bark powder are mixed with butter and applied on swelling part

Boil leaf, mix with N. Sativa \& leaf of Withania sp., A Sativum \& honey and eat the mixture at a time of necessity

Leaf paste is applied on skin diseases and wound; as antiinflammatory

The root is crushed, squeezed, and mix it with water and drink the suspension

Boiled in water and drink it like tea until the symptom is recovered

Dried or fresh root is consumed orally

Dried seed is ground \& mixed with water and drink the suspension in the morning.

Seeds are worn by women as necklace to prevent evil attack

Fresh leaf, stem vapor is used nasally to fumigate the whole body

Eating the crushed leaf when the disease occurred

Bathing with crushed leaf

Pounding $\&$ boiling the rhizome and drink it like drinking tea 
Among all plants recorded, Fabaceae was the most dominant family containing 8 species $(10.4 \%)$ followed by Euphorbiaceae (6 species $(7.7 \%)$, Liliaceae $(6.5 \%)$ and Asteraceae (4 species (5.2\%), respectively. In terms of plant habitus, the majority $(42.8 \%)$ was herbs followed by shrubs $(32.6 \%)$, trees $(20.8 \%)$ and climbers $(3.8 \%)$.

\section{Parts and conditions of medicinal plants used}

Results revealed that the greatest proportion used as medicine are leaves $(54 \%)$ followed by roots (18\%). Other parts include seeds $(16 \%)$, latex $(7 \%)$, stem/bark $(3 \%)$ and whole plant $(2 \%)$. The majority of medicinal plants are harvested from wild vegetation that indirectly shows the presence of high pressure on wild vegetation. Wild vegetation is the source of medicinal plants in many places of Ethiopia as shown by Giday (1999) and Amenu (2007) in Lake Ziway and Ejaji areas, respectively.

\section{Method of remedy preparation and application}

Traditional healers in the study area used various types of preparations in which pounding/pulverizing (36\%) is the major type followed by cooking (14\%), squeezing (10\%), chewing (7\%) and others (33\%). Preparations were administered by different routes: oral (51\%) dermal (31\%), nasal $(9 \%)$, eustachian $(2 \%)$, ocular $(1 \%)$ and fumigation $(6 \%)$ based on the type of the disease.

\section{Fidelity Level (FL) of medicinal plants}

Medicinal efficacy of a species was determined by calculating fidelity level index. In this study, Pterolobium stellatum and Echinops kebercho have high medicinal value against Evil eye and Devil disease, respectively (Table 2). Withania somenifera is reported by $54 \%$ of informants, with FL value of 0.50 is found to be the second species next to Pterolobium stellatum $(\mathrm{FL}=0.80)$ used in the medication of Evil eye.

\section{Preference and direct matrix rankings}

Different plant species are used for the treatment of different ailments. In such cases, local people showed preference towards plant species on the basis of their healing power against a given disease. Key informants were asked to show their preference from eight selected plant species on the basis of treating several diseases and they showed that Allium sativum is the most preferred one followed by Ruta chalepensis (Table 3 ).

Medicinal plant species that have multiple purposes could be screened using direct matrix. In this study, ten multipurpose species were selected out of the total medicinal plants and eight use-categories were listed for 7 selected key informants to assign use values to each species. The informants listed Cordia africana to be highly used by local community for multiple purposes. Juniperus procera, Ficus carica, and Carissa spinarum stood at $2^{\text {nd }}$, $3^{\text {rd }}$ and $4^{\text {th }}$ position, respectively (Table 4$)$. However, the unsustainable use of these plant species for multiple uses made them scarce in the locality.

\section{Major human diseases and corresponding number of plant species used}

In the study area, a total of 36 human diseases and health defects (like injuries) are documented. Of these, 30 ailments $(83 \%)$ are treated using two or more medicinal plant species while 6 ailments $(17 \%)$ are treated using only one plant species (Table 5). Treatment of ailments by more than a single species was reported by researchers in some parts of Ethiopia (Amenu 2007).

Table 2. Fidelity level index for plant species used to treat Evel eye and Devil disease in the study area

\begin{tabular}{lclccc}
\hline Ailments & $\begin{array}{c}\text { \% of } \\
\text { infor- } \\
\text { mants }\end{array}$ & \multicolumn{1}{c}{ Species } & Np & N & $\begin{array}{c}\text { Fidelity } \\
\text { index } \\
\text { (Np/N) }\end{array}$ \\
\hline Evil eye & 54 & $\begin{array}{l}\text { Withania somenifera } \\
\text { Pterolibium }\end{array}$ & 18 & 36 & 0.5 \\
& 9 & 5 & 0.8 \\
& 6 & $\begin{array}{l}\text { Stellatum } \\
\text { Triumfetta pilosa }\end{array}$ & 1 & 4 & 0.25 \\
Devil disease & 7 & Tragia cenera & 1 & 5 & 0.20 \\
& 42 & Capparis tomentosa & 12 & 28 & 0.43 \\
& 9 & Echinops kebercho & 3 & 6 & 0.50 \\
& 9 & Rosa abyssinica & 1 & 6 & 0.20 \\
\hline
\end{tabular}

Table 3. Preference ranking of eight selected medicinal plants on the degree of healing several ailments by key respondents

\begin{tabular}{|c|c|c|c|c|c|c|c|c|c|c|}
\hline \multirow{2}{*}{ Species } & \multirow{2}{*}{ Family } & \multicolumn{7}{|c|}{ Respondents } & \multirow[b]{2}{*}{ Total } & \multirow[b]{2}{*}{ Rank } \\
\hline & & $\mathbf{A}$ & $\mathbf{B}$ & $\mathbf{C}$ & D & $\mathbf{E}$ & $\mathbf{F}$ & $\mathbf{G}$ & & \\
\hline Allium sativum & Liliaceae & 8 & 8 & 7 & 7 & 6 & 7 & 7 & 50 & 1 \\
\hline Ruta chalepensis & Rutaceae & 8 & 8 & 6 & 6 & 7 & 6 & 8 & 49 & 2 \\
\hline Nigella sativa & Ranunculaceae & 8 & 7 & 5 & 7 & 6 & 5 & 7 & 45 & 3 \\
\hline Zingiber officinale & Zingiberaceae & 8 & 6 & 3 & 6 & 4 & 5 & 6 & 38 & 4 \\
\hline Clutia abyssinica & Euphorbiaceae & 7 & 6 & 4 & 5 & 3 & 5 & 6 & 36 & 5 \\
\hline Euphorbia ampliphylla & Euphorbiaceae & 6 & 6 & 2 & 4 & 2 & 5 & 5 & 30 & 6 \\
\hline Carica papaya & Caricaceae & 3 & 3 & 2 & 4 & 2 & 2 & 4 & 20 & 8 \\
\hline
\end{tabular}

Note: A-G: key respondents 
Table 4. Direct matrix analysis of selected medicinal plants based on a general use-value

\begin{tabular}{|c|c|c|c|c|c|c|c|c|c|c|}
\hline \multirow{2}{*}{ Species } & \multicolumn{10}{|c|}{ Use-category } \\
\hline & Medicine & Food & Fencing & Forage & Firewood & Charcoal & Construction & Furniture & Total & Rank \\
\hline Acacia abyssinica & 3 & 0 & 4 & 1 & 4 & 3 & 1 & 0 & 16 & $6^{\text {th }}$ \\
\hline Croton macrostachyus & 4 & 0 & 3 & 2 & 3 & 0 & 3 & 3 & 15 & $7^{\text {th }}$ \\
\hline Piper nigrum & 4 & 0 & 3 & 1 & 3 & 0 & 3 & 3 & 17 & $5^{\text {th }}$ \\
\hline Arundo donax & 4 & 0 & 0 & 2 & 1 & 0 & 0 & 3 & 10 & $9^{\text {th }}$ \\
\hline Pterolobium stellatum & 4 & 0 & 3 & 2 & 0 & 0 & 0 & 0 & 9 & $10^{\text {th }}$ \\
\hline Ocimum lamiifolium & 4 & 0 & 2 & 1 & 3 & 1 & 1 & 0 & 12 & $8^{\text {th }}$ \\
\hline Cordia africana & 4 & 2 & 1 & 3 & 3 & 3 & 3 & 5 & 24 & $1^{\mathrm{st}}$ \\
\hline Ficus carica & 4 & 0 & 2 & 3 & 3 & 2 & 3 & 3 & 20 & $3^{\text {rd }}$ \\
\hline Carissa spinarum & 3 & 3 & 4 & 3 & 3 & 2 & 1 & 0 & 19 & $4^{\text {th }}$ \\
\hline Juniperus procera & 4 & 0 & 4 & 1 & 4 & 1 & 4 & 4 & 22 & $2^{\text {nd }}$ \\
\hline
\end{tabular}

Table 5. Lists of major human diseases and the corresponding medicinal plant species used by rural people of Bahir Dar

\begin{tabular}{|c|c|c|c|}
\hline Diseases (injuries) & $\begin{array}{c}\text { Medicinal } \\
\text { plants } \\
\text { (number) }\end{array}$ & Diseases (injuries) & $\begin{array}{c}\text { Medicina } \\
\text { plants } \\
\text { (number) }\end{array}$ \\
\hline Stomach complaints & 17 & Swelling & 4 \\
\hline Devil' disease & 7 & Tonsillitis & 2 \\
\hline Diarrhea & 4 & Ascaris & 2 \\
\hline Eczema & 4 & $\begin{array}{l}\text { Miscarriage } \\
\text { (abortion) }\end{array}$ & 1 \\
\hline Hepatitis & 4 & $\begin{array}{l}\text { Infection on } \\
\text { swelling }\end{array}$ & 1 \\
\hline Hair fungus & 2 & Heart disease & 1 \\
\hline Febrile (fever) & 2 & Diabetic & 7 \\
\hline Malaria & 8 & STDS & 2 \\
\hline Hemorrhoid & 4 & Broken leg/hand & 3 \\
\hline 'Evil eye' & 7 & Eye disease & 2 \\
\hline $\begin{array}{l}\text { Erectile dysfunction } \\
\text { (Impotence) }\end{array}$ & 3 & Sudden sickness & 4 \\
\hline Cancer & 3 & Skin rash & 4 \\
\hline $\begin{array}{l}\text { Snake biting and } \\
\text { scorpion bite }\end{array}$ & 1 & Face fungus & 2 \\
\hline Ringworm & 3 & Boil & 1 \\
\hline Cough & 4 & Allergic & 1 \\
\hline Wound sore & 6 & Common cold & 5 \\
\hline Headache & 4 & Tumor & 4 \\
\hline $\begin{array}{l}\text { Placental retention } \\
\text { (delay) }\end{array}$ & 4 & Hypertension & 2 \\
\hline
\end{tabular}

In conclusion, this study revealed the use of medicinal plants by rural community of Bahir Dar City for maintaining their primary health care. The use of herbals has been an age-long practice in the area. Despite their irreplaceable use, the future existence of medicinal plants resource and the associated knowledge is under question because of the ongoing practice of urbanization, deforestation, agricultural encroachment, overgrazing and overexploitation. So, in-situ and ex-situ conservation strategies of medicinal plants should be adopted and implemented by training the practitioners. The local government should organize medicinal practitioners in association(s) in such a way that their valuable knowledge can be used along with modern medicine.

\section{ACKNOWLEDGEMENTS}

The authors are grateful to the informants for sharing their incredible accumulated knowledge. We thank Andargachew Baye (team member of the Amhara National Regional State GIS group) for constructing map of the study area for us.

\section{REFERENCES}

Abebe D. 1986. Traditional medicine in Ethiopia. The attempt being made to promote it for effective and better utilization. SINET: Ethiop J Sci 9:61-69.

Alexiades MN. 1996. Collecting ethnobotanical data: An introduction to basic concepts and techniques. In: Selected Guidelines for Ethnobotanical Research: A Field Manual. The New York Botanical Garden, New York.

Amenu E. 2007. Use and management of medicinal plants by indigenous people of Ejaji area (Cheliya Woreda), West Shoa, Ethiopia: An ethnobotanical approach. [Thesis]. Addis Ababa University, Ethiopia.

Bekele A. 2007. Useful trees and shrubs for Ethiopia. World Agroforestry Centre, East Africa Region, Nairobi, Kenya.

Dagne. E. 2009. Natural database for Africa. Version 1, Addis Ababa, Ethiopia.

Edwards S, Tadesse M, Demissew S, Hedberg I. 2000. Flora of Ethiopia and Eritrea Volume 2, Part 1 Magnoliaceae to Flacourtiaceae. Uppsala University, Uppsala, Sweden.

Flora of Ethiopia and Eritrea, volumes 1-8. https://www.nhbs.com/series/flora-of-ethiopia-and-eritrea. Accessed November 2018 - May 2018.

Giday M. 1999. An Ethnobotanical study of Medicinal Plants Used by Zay People in Ethiopia. [Thesis]. Uppsala, Sweden.

Hedberg I, Edwards S, Demissew S. 1997. Flora of Ethiopia and Eritrea, Volume 6 Hydrocharitaceae to Arecaceae. Uppsala University, Uppsala, Sweden

Hedberg I, Edwards S, Nemomissa S. 2003. Flora of Ethiopia and Eritrea, Volume 4, Part 1 Apiaceae to Dipsacaceae. Uppsala University, Uppsala, Sweden

Hedberg I, Edwards S, Tadesse M. 1995. Flora of Ethiopia and Eritrea, Volume 2, Part 2 Canellcaeae-Euphorbiaceae. Uppsala University, Uppsala, Sweden

Hedberg I, Edwards S. 1989. Flora of Ethiopia, Volume 3 Pittosporaceae Araliaceae. Uppsala University, Uppsala, Sweden

Hedberg I, Edwards S. 1995. Flora of Ethiopia and Eritrea, Volume 7 Poaceae (Gramineae). Uppsala University, Uppsala, Sweden

Hedberg I, Edwards S. 2007. Flora of Ethiopia and Eritrea, Volume 5. Uppsala University, Uppsala, Sweden

Hedberg I, Friis I, Persson E. 2009a. Flora of Ethiopia and Eritrea, Volume 1 Lycopodiaceae to Pinaceae. Appendix: Additions and amendments to vols. 2-7. Uppsala University, Uppsala, Sweden 
Hedberg I, Friis I, Persson E. 2009b. Flora of Ethiopia and Eritrea, Volume 8, General part and index to vols 1-7. Uppsala University, Uppsala, Sweden

Martin.GJ. 1995. Ethnobotany: A method manual. Royal Botanical Garden. Chapman and Hall, Kew, London.

Nair M, Nathan G. 1998. Medicinal plants: cure for the 21 st century. Biodiversity, conservation and utilization of Medicinal plants. Proceedings of the Seminar UPM, Serdang, Malaysia.
Seid MA, Tsegay BA. 2011. Ethnobotanical survey of traditional medicinal plants in Tehuledere district, South Wollo, Ethiopia. J Med Plants Res 5 (26): 6233-6242.

Seifu T, Asres K, Gebremariam T. 2006. Ethnobotanical and Ethnopharmaceutical studies on medicinal plants of Chifra district, Afar Region, Northeast Ethiopia. Ethiop Pharm J 24: 41-58. DOI: 10.4314/epj.v24i1.35097

Tadesse M. 2005. Flora of Ethiopia and Eritrea, Volume 4, Part 2 Asteraceae (Compositae). Uppsala University, Uppsala, Sweden 